International Review of Social History 45 (2000), pp. 159-177

(C) 2000 Internationaal Instituut voor Sociale Geschiedenis

\title{
Finding the Right Balance: Financial Self-Help Organizations as Sources of Security and Insecurity in Urban Indonesia*
}

\author{
HOTZE LONT
}

Financial self-help organizations can be found in many parts of the world, and the cities of Java are among the areas where they are particularly widespread. Since about the 1950s, interest in these institutions among anthropologists and development sociologists has increased considerably. ${ }^{1}$ Analyses of financial self-help organizations have most often focused on their economic or their social function; few scholars have pointed to their function as providers of security and identified self-help organizations as typical forms of local social security institutions. ${ }^{2}$ The main shortcoming of most of these studies is that they base their conclusions solely on an analysis of the financial arrangements provided by these self-help organizations, neglecting the accommodating practices that people undertake in order to fit the provisions of self-help organizations to their own household needs. This essay explores the observation that financial self-help organizations do not simply provide

\footnotetext{
* I am grateful to Peer Smets for the helpful comments I received from him while writing this article. The article is based on quantitative and qualitative data gathered during fieldwork that took place between August 1997 and August 1999. This research is sponsored by the Royal Netherlands Academy of Arts and Sciences (KNAW).

I. For a good overview of the literature on financial self-help organizations, see J.N. Kerri, "Studying Voluntary Associations as Adaptive Mechanisms: A Review of Anthropological Perspectives", Current Anthropology, 17 (1976), Pp. 23-47; F.J.A. Bouman, "ROSCA: On the Origin of the Species", Savings and Development, I9 (1995), Pp. II7-I48; and Hari Srinivas, "The Virtual Library on Microcredit [Online]", available at: http:/www.soc.titech.ac.jp/icm/icm.html (accessed i7 February 2000).

2. See for example F. von Benda-Beckmann et al., "Introduction: Between Kinship and the State", in F. von Benda-Beckmann et al. (eds), Between Kinship and the State: Social Security and Law in Developing Countries (Dordrecht, 1988), pp. 7-20, 16; F.J.A. Bouman, "ROSCA and ASCRA: Beyond the Financial Landscape", in F.J.A. Bouman and O. Hospes (eds), Financial Landscapes Reconstructed: The Fine Art of Mapping Development (Boulder, CO, 1994), pp. 375-394, 375, 381; J. Midgley, "Social Security Policy in Developing Countries: Integrating State and Traditional Systems", Focaal, 22/23 (1994), pp. 219-229, 223; G.R. Woodman, "The Decline of Folk-Law Social Security in Common-Law Africa", in von Benda-Beckmann et al., Between Kinship and the State, pp. 69-88, 81; W. van Ginneken, "Overcoming Social Exclusion", in W. van Ginneken (ed.), Social Security for the Excluded Majority: Case Studies of Developing Countries (Geneva, 1999), pp. 1-36, 20-26; V. Gerdes, "Precursors of Modern Social Security in Indigenous African Institutions", The Journal of Modern African Studies, 13 (1975), pp. 209-228. J.-P. Platteau, “Mutual Insurance as an Elusive Concept in Traditional Rural Communities", The Journal of Development Studies, 33 (1997), pp. 764-796, has very justifiable reservations as to whether these institutions, and other "traditional" collective arrangements, teally embody the concept of mutual insurance as we understand it in developed market economies.
} 
security through the different kinds of insurance mechanisms they might contain, but that, particularly through the way in which people use them and participate in them, these institutions become meaningful for coping with insecurity. It examines the question of whether participation in financial self-help organizations contributes to the ability of households to cope with adversities and deficiencies in a concrete social context. Research aiming to answer this question was conducted in Bujung, an urban ward on the outskirts of Yogyakarta, on the island of Java. ${ }^{3}$

The argument of this essay requires concise introductions to the characteristics of financial self-help organizations in Bujung, and of households and their financial insecurities. It then goes on to explain the different ways in which people try to cope with the financial insecurities they face and how financial self-help organizations play a role in this.

\section{FINANCIAL SELF-HELP ORGANIZATIONS}

A financial self-help organization is an association of a number of people who decide to pool money in a collective fund. There are three basic types of arrangement found in the Bujung area. The first is the arisan, an arrangement whereby the participants regularly contribute money to form a kitty. The kitties that are built up in this way are distributed to each participant in rotation; the sequence being usually determined by lot, and sometimes by bidding. ${ }^{4}$ The second type is the simpan pinjam, whereby participants do not contribute to a kitty but to a loan fund. Members of the organization can borrow money from the fund and repay these loans at a modest rate of interest. This way the total capital of the self-help organization can accumulate over time. The third arrangement, which in practice is found only in addition to the simpan pinjam, is the "special fund". In this system money is contributed to a collective fund used to make disbursements to its members in the event of adversity (such as death, illness or accidents). The sums provided through these arrangements are relatively small and the support they provide is more symbolic than substantial. ${ }^{6}$ One single financial self-

3. Bujung itself has around 6,000 inhabitants, whereas the city of Yogyakarta as a whole contains around 500,000 people. The inhabitants of Bujung range from civil servants to scavengers, from pedicab drivers to traders, from poor to lower middle class basically. The poorer inhabitants of Bujung tend to live together along the rivers, more or less separated from their wealthier neighbours. 4. In the literature on financial self-help organizations these arrangements are usually termed ROSCAs (Rotating Savings and Credit Associations). A formal definition can be found in S. Ardener, "Women Making Money Go Round: ROSCAs Revisited", in S. Ardener and S. Burman (eds), Money-Go-Rounds: The Importance of Rotating Savings and Credit Associations for Women (Oxford, 1995), pp. I-19, I.

5. This arrangement is usually termed ASCRA (Accumulating Savings and Credit Associations). A formal definition can be found in Bouman, "ROSCA and ASCRA", p. 376.

6. This type of arrangement has been termed SAVA (Savings Association). See P. Smets, Informal Housing Finance in Hyderabad, India, Urban Research Working Papers No. 40 (Amsterdam, 1996), p. 55. 
help organization can host several of these arrangements. Such organizations are often termed arisan, even if they have a simpan pinjam and special funds as well. In Bujung these arisan and simpan pinjam have become prominent institutions in daily life, with several meetings being held in different places every day.

A rich variety of financial self-help organizations can be found in Bujung. There are, for example, organizations managed by individuals and by committees, organizations with membership based on gender, occupation, or neighbourhood, organizations with meetings and without meetings, officially-registered cooperatives and "informal" organizations, organizations with one single financial arrangement and organizations with a myriad of activities, obligatory and voluntary organizations, large organizations and small organizations, organizations initiated by the government, and independent organizations. The most numerous category are the self-help organizations linked to the Rukun Tetangga, or neighbourhood section. In urban Indonesia, each Rukun Tetangga (RT) has obligatory associations for the men, the women, and the youngsters, usually one per approximately forty households. These organizations form the basis for coordinating all kinds of neighbourhood activities, and lotteries are held to attract people to the meetings and to generate funds for various social projects and local initiatives.

Altogether, the inhabitants of Bujung participate in hundreds of different financial self-help organizations, ${ }^{8}$ and each of them is unique. Even so, apart

7. There are many references that mention or discuss the existence of ROSCAs in Java, referred to locally as arisan. The most important are C. Geertz, "The Rotating Credit Association: A 'Middle Rung' in Development", Economic Development and Cultural Change, 10 (1962), pp. 24I263; and H. Papanek and L. Schwede, "Women are Good with Money: Earning and Managing in an Indonesian City", in J. Bruce and D. Dwyer (eds), A Home Divided: Women and Income in the Third World (Stanford, CA, 1988), pp. 71-98. ASCRAs, referred to locally as simpan pinjam, have been discussed by inter alia: (in west Java) T.J. Scheepens, "Socio-economic Research about Traditional Savings and Credit Associations in Comparison with Modern Organizations in Desa Bojong, Jawa Barat, Indonesia” (M.A., Wageningen Agricultural University, 1974); (in central Java) G. Williams and M. Johnston, "The Arisan: A Tool for Economic Development?", Prisma The Indonesian Indicator, 29 (1983), pp. 66-73; and (in east Java) S. Cederroth, Survival and Profit in Rural Java: The Case of an East Javanese Village (Richmond, VA, 1995), pp. 181-187. Selosoemardjan, Social Changes in Jogjakarta (Ithaca, NY, 1962), pp. 314-323, mentions a number of ASCRAs started as a private initiative by people in and around Yogyakarta as early as the 1940s.

8. The average number of financial self-help organizations per household in Bujung is $4.8 \mathrm{I}$ (total 156). There was not a single household in our sample in which none of the members participated in financial self-help organizations. Compare this with two surveys - one in Bolivia: D.W. Adams and M.L. Canavesi de Sahonero, "Rotating Savings and Credit Associations in Bolivia", Savings and Development, 13 (1989), pp. 219-236, 224, and one in India: P. Smets, My Stomach Is My Bishi: Savings and Credit Associations in Sangli, India, Urban Research Working Papers No. 30 (Amsterdam, 1992), pp. II-I2. The participation rate in financial self-help organizations was found to be between 30 per cent and 40 per cent (total 450 ) in the case of Bolivia and 58 per cent (total $326)$ in the case of India. The data were gathered in a different manner, but it is clear that the participation rate in Bujung is very high; to a large extent this can be explained by the obligatory character of the arisan RT. 
from money being pooled, there are a few other commonalities. First, the participants have some role in the decisions made about the activities of the organization; thus the organizations are self-administering and free to determine, for instance, selection criteria and the size of loans and interest rates. Secondly, the participants can acquire lump sums from financial selfhelp organizations, ranging from Rp. 10,000 to Rp. 10,000,000. ${ }^{9}$ This way, what financial self-help organizations basically do is to transform small sums of money (contributions, instalments) into larger amounts (loans, kitties).

\section{HOUSEHOLDS AND MONEY}

In practice, it is very difficult to discern the boundaries of Javanese households because there may be relatives or friends who regularly join in at meals or spend the night, and children and parents may work somewhere else and spend considerable time outside the house. Conceiving households loosely as home-based budget-pooling units, one can say that most households in Bujung comprise two parents with one or more children. ${ }^{10} \mathrm{Occu}-$ pational multiplicity is the standard for households in Bujung. Not only does the household income come from various household members, each person generally derives an income from various sources. In most households the income of both partners is substantial, but that of the husband is usually higher than his wife's. ${ }^{\text {II }}$ In cases where unmarried youngsters earn an income of their own, they are generally free to spend it for themselves. With a few exceptions, they are asked to contribute only in the event of deficiencies.

The generally accepted view among anthropologists of Indonesian households as budget-pooling units is that women, much more than in other societies, have decision-making power over the household budget. ${ }^{\mathrm{I2}}$ In my

9. During my fieldwork the rate of the Indonesian rupiah fluctuated between Rp. 2,400 and Rp. I5,000 to the US dollar. For comparison, over this period the daily wage of an unskilled construction worker rose from Rp. 5,000 to Rp. I0,000.

Io. In the two neighbourhood sections where I concentrated my fieldwork, there were fifty households consisting of two parents and one or more children ( 55.6 per cent), twelve households consisted of two parents, one or more children, and one or more grandparents (I3.3 per cent), and nine households with a single mother and one or more children (Io per cent). The remaining nineteen households fell into other smaller categories.

II. It proved to be very hard to quantify the size of the contributions of women in these households because there is a strong tendency among both women and men to dismiss the income earning activities of the wife as "just helping the husband" (bantu-bantu suami).

12. Examples of authors observing a strong position for women in the household are R.R. Jay, Javanese Villagers: Social Relations in Rural Modjokuto (Cambridge, MA, 1969), pp. 92-93; L. Manderson, "Introduction", in L. Manderson (ed.), Women's Work and Roles: Economics and Everyday Life in Indonesia, Malaysia and Singapore, ANU, Development Studies Center, Monograph No. 32, (Canberra, C.T., I983), pp. I-I4, 6; and Papanek and Schwede, "Women are Good with Money", pp. 89-9I. Others observed some involvement by men in decisions, especially those on major expenditure: H. Geertz, The Javanese Family: A Study of Kinship and Socialization (New 
view this is an oversimplification. The degree to which women control household money is severely limited in many cases. This becomes clearest by looking at the different components of the household budget. Zelizer ${ }^{\mathrm{r}}$ has shown, in a quite different context, that not all money is the same, and that people might distinguish between different kinds of money based on its origin, destination, amount, etc. It is possible to make a somewhat artificial, but realistic, distinction between three different kinds of money within the household budgets in Bujung. This distinction is based on who is entitled to decide about the money. Shopping money (uang belanja), which is used to cover daily household expenses, is controlled by the wife, and only a few husbands keep a close eye on how she spends this. Apart from that, individual members of the household can use pocket money (uang jajan) for private purposes. Husbands, children and elderly all have pocket money, while wives have to manage with their shopping money. The third kind of money is stocked savings. This is money locked for future expenditures. This money might be kept in a special jar in the house, at the bank, with a financial self-help organization, or in the form of durable goods. Whether and when this money will be used is usually the joint responsibility of the husband and wife. Which of them has the biggest say in this is partly determined by the origin of the money, but there is ample scope for negotiation.

Even though the wife has sole responsibility for the way shopping money is spent, the husband has the final say on the actual quantity earmarked as shopping money, since that money consists of the earnings of the wife plus whatever additional contribution is made by the husband. A few "good" husbands simply contribute all their income and ask for money every time they want to buy cigarettes, for example. Their wives are often able to save relatively large amounts of shopping money, sometimes in secret jars, so expanding their own financial room for manoeuvre by creating stocked savings under their own authority. Other husbands take a small amount from their own income before they give it to their wives, and use this for buying cigarettes, an occasional snack, and for gambling. Finally, there are

York, 1961), p. 125; and W. Keeler, "Speaking of Gender in Java", in J.M. Atkinson and S. Errington (eds), Power and Difference: Gender in Island Southeast Asia (Stanford, CA, 1990), pp. 127-152, 129. D.L. Wolf, Factory Daughters: Gender, Household Dynamics, and Rural Industrialization in Java (Berkeley, CA, 1992), p. 65, argues that proper observation shows that men make the decisions in the household. Keeler, "Speaking of Gender in Java", p. 128; Wolf, Factory Daughters, p. 66; and A. Stoler, "Class Structure and Female Autonomy in Rural Java", Signs, 3 (1977), pp. 74-89, emphasize that any economic role that women may have in the Javanese household does not lead to their having a similar position in other social spheres.

13. V. Zelizer, "The Special Meaning of Money: 'Special Monies', American Journal of Sociology, 95 (1989), pp. 342-377. Zelizer describes the special status of household money for housewives in the United States. She argues that "culture and social structure mark the quality of money by institutionalizing controls, restrictions, and distinctions in the source, uses, modes of allocation, and even the quantity of money", p. $34^{2}$. 
also the "tough" ${ }^{n_{14}}$ husbands, who make a conservative calculation of the shopping money their wives will need, and keep the rest as pocket money. In these households there are frequent quarrels about money, and wives have to negotiate and cheat in order to obtain a more realistic budget. In the households where the shopping budget is tight, stocked savings or pocket money regularly have to be mobilized for shopping. Where shopping money is generally more than enough, the wife is able to save part of it for future needs.

Obviously, within the limitations caused by these cultural perceptions of money, both husbands and wives have an interest in maximizing their control over household money. Their financial negotiations can go along different lines. Two reasons why it would be fair for a woman to receive more shopping money are that the costs of shopping are higher than estimated, or that her own income is lower than expected. Most men find it very difficult to check whether the financial picture presented by their wives is true or not, and that provides wives with an opportunity to juggle with the truth. Numerous women who have a hard time negotiating over shopping money consistently lie about the size of their own income, conceal their personal savings, and exaggerate household expenses. Many men naturally have a gut feeling that they cannot rely on their wives' version of the story, and therefore they try to restrict their contribution to the shopping budget to some conservatively estimated minimum, and in some cases they even lie about their own income as well. Wives may also try to play on their husbands' sentiments. They can either claim to be pitiful, by begging and whining, or claim he is pathetic by publicly denouncing him as a loser, who is unable to support his family in a decent way. Other women do not opt for confrontation, and choose to look for work if there is not enough money coming from their husbands. Many of them engage in home production or start working as maids, mainly because they want to have more shopping money. However, this may have the adverse effect of encouraging husbands to believe that they can keep more money for themselves and contribute less to the household.

In general, one can say that in Bujung the wife manages the household budget, but it is more precise to say that she is in charge of one of the household budgets. Shopping money is the responsibility of the wife, while stocked savings are managed by husband and wife. The relative sizes of both budgets and thus the financial autonomy of the wife are determined by how much the husband is willing to contribute to the household budget. If the husband is willing to contribute a lot, then the wife will have sufficient financial scope to determine how much money she wants to have for shopping and how much she wants to save. If the husband is not willing, or

14. The qualifications "good" and "tough" (baik and keras in Indonesian) were used by female informants. 
simply unable, to contribute enough, then the wife faces financial problems. Households can be understood as budget-pooling units, but the individual members of the household never pool all their financial resources, and not all members of the household have the same entitlements to the different monies in the household budget. Households cannot and should not be understood as acting as a unit, but rather as an arena for negotiation between interdependent individuals.

\section{EMERGING FINANCIAL INSECURITIES}

Because of their occupational multiplicity, most households in Bujung experience a complex mix of income cycles, where part of the money may arrive on a daily basis, another part on a monthly basis, and the rest every once in a while. There is limited access to stable income in Yogyakarta because the competition for regular jobs and good sites for street trading is stiff. Even if one does have access to a stable income, the total amount is rarely enough for a household to survive. Even the civil servants in Bujung depend heavily on irregular bonuses and have to invest in private enterprise in order to make ends meet.

A monthly income is normally associated with civil servants and with employees of private companies (20.I per cent of workers), ${ }^{15}$ but the many housekeepers and laundry ladies in the ward (8.I per cent) also get their wages once per month. Such a monthly income is conveniently reliable and forms a good basis for taking care of fixed monthly expenditures, like school fees. The disadvantage of a monthly income is that one has to be very careful with spending, otherwise there will be nothing left at the end of the month. ${ }^{16}$ Households that rely largely on a weekly income share the same problems of financial planning, but they may find it more difficult to deal with larger expenditures. The weekly income is typical for labourers in small enterprises, such as workshops and retail shops (9.2 per cent). However, most people earn a daily income, which is more or less uncertain for almost all of them. There are daily incomes for small food traders, home producers, pedicab drivers, construction workers, parking guards, taxi drivers, coolies, scavengers, shopowners, etc. These people have to find ways to deal with days on which there is no income, or only very little, and for them especially it is difficult to deal with larger expenditures.

When discussing fluctuations in income with informants in Bujung, the words sepi and rezeki were used time and again. Sepi means quiet, and is often the primary reason for a slackening in income. When things are sepi,

15. The quantitative data on Bujung in this article are based on a questionnaire among 156 households in July 1998.

16. For example, wives of civil servants regularly complained that they worried about making ends meet at the end of the month, and a woman who went around houses selling breakfast snacks each morning told me that her turnover was significantly less at the end of the month. 
traders have few customers and irregular workers have very few jobs. The word rezeki is, in a way, its counterpart, has connotations of luck, and is used to refer to a windfall, a sudden income, relatively large and more or less unexpected. It is a particular feature in the fluctuation of incomes in Bujung. The regular "special bonuses" of civil servants are considered rezeki. Pedicab drivers may have many customers on one day, or just one tourist who pays exceptionally well. Coolies can suddenly have a heavy, but wellpaid job. The housewives who travel each year to the northern Javanese city of Pekalongan before the Idul Fitri holiday to pack parcels for a few weeks consider this income rezeki. And of course winning the lottery is also rezeki. People in Bujung like to use their rezeki for something special, like buying new clothes or presents for their grandchildren. However, many people are forced to use part of it to repay their debts, as a way to balance money cycles. A civil servant working at the veterinary lab of Gadjah Mada University said:

Whenever our wages are not enough and the money has already been spent, we pray for rezeki from the Lord. If we believe strongly enough, it will come. What might happen is that a person comes to the lab who needs to have a picture for something. If he is a good person he gives me some extra money for that. That can solve our problems. And otherwise I still have my cocks. I just take one of them to the market and sell it. When another rezeki befalls me I buy a new one.

Without rezeki many people would have difficulty taking care of large or unexpected expenditures.

Also, expenditures are not evenly divided over time. Four of the most important expenditure items for households in Bujung relate to food, education, financial contributions (sumbangan) and hospital treatment. The largest part of the household budget is spent daily on shopping at local shops and at the market, and the average amount spent each day is quite stable. Education for children at primary school also requires daily payment, but for children at secondary school fees have to be paid per month, with additional annual fees. Small financial contributions have to be made for ill or deceased neighbours, and considerably higher contributions in the event of a marriage, events that tend to be concentrated in the four popular wedding months. Furthermore, there are regular contributions to the RT for administration and building costs. Finally, the costs of hospital treatment are clearly not regular expenditure, but if people in Bujung are seriously ill it is quite common to opt for hospital treatment, the costs of which are nearly always quite a burden. ${ }^{17}$ These, more or less irregular, costs make for a complex mix of cycles of expenditure as well.

Together, the insecure composite incomes and irregular costs make for unbalanced financial cycles within the household economy. For most people in Bujung, these cycles create insecurities in the form of emerging financial

17. For the 39.I per cent of households that do not own the house in which they live, the annual rent is a problematic expenditure as well. 
disparities. A clear example is an independent coolie, who may earn Rp. 40,000 one day and almost nothing for the next few days. He will find it difficult to make ends meet on a day-to-day basis. However, in different ways nearly everybody in Bujung, whether they are "poor" or "lower middleclass", unskilled labourers, successful traders or civil servants, is to a larger or lesser degree confronted with unpredictable financial problems. Hardly anybody can rely on a safe financial buffer, and too large a financial disparity can have disastrous consequences for a household's living standard. In the light of this, one could define responsible household management as spending as one earns, not more. However, it has also become clear that in Bujung, probably like anywhere else in the world, this is an unrealistic expectation. Costs and loss of income can be uncertain, and some expenditure, like the payment of school fees, cannot easily be postponed. Or income is received in small daily amounts, while expenditures might be infrequent and large. In other words, there is often a time lag between expenditure and earnings, and households have to find ways to balance these unbalanced financial cycles.

\section{COPING WITH FINANCIAL DISPARITIES}

Savings are a useful, and in Bujung generally preferred, resource for dealing with the financial disparities created by fluctuations in income and expenditure. Obviously, saving money is difficult for those who have small incomes with few regular extras. In many cases their own desire to consume is the most dangerous enemy for those who want to save. Many of my informants felt unhappy about all the money they spent on clothing, gambling, and the snacks provided by the numerous peddlers frequenting the neighbourhood. Apart from that, people in Bujung are also confronted with frequent financial claims from others, in and outside their own households. Each day, women have to confront children and husbands who are looking for pocket money, and neighbours and relatives regularly visit to ask for gifts or loans to meet their needs. In view of these problems, people are looking for some coercive means to save, for a means to hold on to their savings.

Bouman has introduced the notion of illiquidity preference as a logical response in many social contexts in developing countries. ${ }^{18}$ By illiquidity

18. F.J.A. Bouman, "Informal Rural Finance: An Aladdin's Lamp of Information", in Bouman and Hospes, Financial Landscapes Reconstructed, pp. 105-122, 117-118. The same mechanism also explains why some people prefer to borrow money (from their boss, a moneylender, or simpan pinjam) even when they still have stocked savings somewhere. They will often have acquired their savings as the result of a windfall or strong self-constraint and therefore consider it a waste to spend that money too easily. An elderly tailor for instance said: "My gold ring is worth Rp. 250,000. It is a sort of savings, but I never want to sell it. I am too afraid that I will never be able to buy a new one." A loan is preferred because that way they will be forced to repay it regularly, whereas savings are not so easily renewed. 
preference he means that people are looking for mechanisms through which they find it easier to save and more difficult to spend. This objective can be achieved in many different ways, and several of them can be observed in Bujung as well. For example, many people make use of piggy banks that have to be broken open before the money can be spent. Women often have special purpose tins in their closet, where they save small sums, for example for school fees or sudden costs, not allowing themselves to spend it on anything else. Larger sums are brought to a bank account, invested in building material, or converted into gold. When they want to spend money, people who make use of these techniques are automatically confronted with a mix of physical and moral constraints that they themselves have put in place.

Even though making yourself save is the most preferred and respected way of balancing financial cycles, many people are unable or unwilling to postpone consumption and spending. Instead they buy on credit or borrow money from neighbours, relatives, moneylenders, pawnshops, etc. ${ }^{\text {I9 }}$ Various people said that they saw borrowing as a form of saving as well, with the pattern of putting money aside and then spending it reversed. If people use loans as a means to bridge financial disparities, they tend to be in debt continuously. Because most debts require repayment at some stage, the borrowing behaviour of people in Bujung frequently evolves towards a practice that is locally referred to as gali lobang tutup lobang, ${ }^{20}$ or repaying debts with debts. For instance, a person may urgently have to repay a debt to a pawnshop. Because he has no money, he borrows from a friend, perhaps promising to pay him back when a loan is available from a simpan pinjam.

Repaying debts with debts has clear negative connotations in Bujung and is ascribed to irresponsible, lazy and uneducated people. In spite of this generally held perception, held even by those who engage in it themselves, the practice of repaying debts with debts has unmistakably positive aspects, especially for those people with a low level of income stability. It makes it possible to keep debts fresh. This is very important given the pressure that can grow when a debt is not repaid soon enough. Failure to repay debts on time can create tensions, conflicts and loss of reputation, but it can also mean the loss of the goods that served as collateral for the loan, not to mention high interest payments. Repaying debts with debts makes it possible to adjust the repayment time of loans to the income flows of the household; different sources of credit are made complementary. The practice over-

19. For extensive descriptions of the complexities of saving and credit practices, and comparisons between the various sources of finance, see also O. Hospes, People That Count: Changing Savings and Credit Practices in Ambon, Indonesia (Amsterdam, 1996), pp. 41-131; and H.B. Lont, "When We are Broke [...]: Managing Unbalanced Cycles of Money in Urban Households, Yogyakarta, Indonesia", in P. Smets (ed.), Money and Culture, Urban Research Working Papers No. 44 (Amsterdam, 1999), pp. 7-26, 13-17.

20. Literally the expression means "dig a hole, fill a hole". 
comes financial disparities. A preference for gali lobang tutup lobang can create insecurities as well. In times of crisis, whether on a personal or a national level, it is difficult to keep the chain of debts under control, and people are aware of this risk. In Bujung, the story of Marzuki, a pedicab driver who liked drinking and gambling, is often recalled. Marzuki was always in debt, but he was always able to repay his debts sooner or later. One day Marzuki, together with his neighbours, was offered the opportunity to buy his house at a relatively cheap price. He took the offer and borrowed money to pay for the house, but the loan turned out to be a little beyond Marzuki's means and he had problems repaying it. Not long afterwards, Marzuki fell ill. According to the stories, it was the stress of having to repay the large loan that made him sick. Marzuki had to stop working and he could no longer repay his debts. When his condition became serious, there was no longer any money to bring him to the hospital, and so he died.

A chain of debts can get out of control if someone fails to estimate his repayment capability correctly. Also, even though that person may well understand that he or she will not be able to repay these debts in the future, the circumstances might be so pressing that they are simply forced to borrow. The practice of repaying debts with debts also creates the problem of a damaged reputation. In Bujung, the creditworthiness of a person is very much determined by his or her reputation in financial affairs. Making regular use of gali lobang tutup lobang in order to repay urgent debts can enhance one's reputation, but miscalculations can weaken it.

The way these issues become manifest in practice and the ways in which participation in financial self-help organizations are related to the problems of financial disparities becomes clear from the following case studies of two households in Bujung.

\section{SURONO AND RATMI}

Surono and his wife Ratmi work together on Jalan Malioboro, Yogyakarta's main shopping street. Surono is a parking guard for motorcycles and Ratmi sells drinks and cigarettes at the same site. His income as a parking guard is not very much because the revenues have to be shared with the city government and a military officer who owns the site. Surono's daily income may range from $\mathrm{Rp}$. I,500 to $\mathrm{Rp}$. 5,000. The major attraction of working as a parking guard is that one is entitled to sell drinks and cigarettes. The income from that can easily be Rp. I0,000 a day. On busy days it can be more. "Once, we were very lucky and we made 2 million in a week. That week we had to serve hundreds of cups of coffee to guests at the hotel behind our spot." Occasionally Surono also works as a makelar (broker) for people who want to sell motorcycles, land and houses. With their savings they have also built a house further up their alley, which they let for Rp. 
500,000 per year. Surono and Ratmi are in their early forties and have three children, who are eight, thirteen, and fifteen years old.

The couple participate in a host of different financial self-help organizations. Like most men in Bujung, Surono participates in the men's arisan in his RT. Apart from that, there is also the simpan pinjam UKK and the arisan Hansip. Ratmi is in the women's arisan in the RT and Dasa Wisma. There is also the Absari RT, the Absari RW, the UP 2 K and the $\mathrm{P}_{2} \mathrm{WKSS}^{2}{ }^{2}$ Together they participate in two privately organized arisan in their neighbourhood. In one of them they have one share; in the other they have three. And finally, there is also the arisan among the streetside traders of Malioboro, which they participate in as well. Their oldest daughter is a member of the arisan for youngsters in their RT. Surono explains that there are various reasons to participate in these self-help organizations:

The most important reason why we participate in all these organizations is that we like to meet a lot of people. By attending these meetings you can make friends. People will know who you are and where you live. Where else would we meet people? If you and us never went to meetings, we would never have met. Apart from that the financial aspect is also important, especially with organizations such as UKK and the privately organized arisan. In Indonesian culture it is important to give gifts when there is a wedding, a child is born, or someone has died. Therefore you regularly have to spend substantial amounts. By joining all these organizations we ensure that there is always some way of meeting these expenditures.

Later, Surono and Ratmi also make clear that participation in financial self-help organizations has a strong direct meaning for their own household. The lump sums that they derive from the various self-help organizations play an important role in expanding and diversifying their enterprise. For example, with money from an arisan they bought a second-hand motorcycle in order to make it easier to transport goods to their trading site. With a loan from UKK they paid Rp. 350,000 as security for a vending cart from Sosro, a large soft drinks company. It allowed them to have a much broader assortment of drinks. Later, they used money from financial self-help organizations to purchase two pushcarts in order to sell food and fruit ices as well.

Surono and Ratmi take their participation in arisan and simpan pinjam very seriously:

2I. UKK stands for Usaha Kesejahteraan Keluarga, or Family Welfare Enterprise, a self-help organization set up by local leaders of the ward. Dasa Wisma, or Dawis, is a subgroup for women in each Rukun Tetangga. Absari is an organization for women who follow birth control. RW stands for Rukun Warga and is a coordinated collection of five or six Rukun Tetangga. UP2K stands for Usaha Peningkatan Pendapatan Keluarga (Enterprise for the Enhancement of Household Income). P2WKSS stands for Peningkatan Peranan Wanita menuju Keluarga Sehat Sejahtera (Enhancement of Women's Role in Support of the Health and Welfare of the Family). The last two organizations are voluntary activities of PKK, the national women's organization. 
The advantage with arisan is that it becomes a fixed expenditure. You can count on it. Every month there is the electricity bill and the water bill. In the same way, we know that on certain dates we have to spend money on the arisan. If we tried to save alone, we would miss all the social contacts and we would also not be able to save as much as we save now. If you join many, this also reduces the risk of not having money to pay an arisan. If you see this problem coming, you just borrow from a simpan pinjam beforehand. It is a question of financial management. If you have good management, things can be less expensive. You can see the same thing in our enterprise: by buying our own motorcycle we were able to cut back on our transportation costs, and if we have a broader assortment we sell more drinks.

Still, they cannot rely entirely on financial self-help organizations and sometimes they also make use of other sources of finance. When they built their second house there was a mistake in calculating the costs. It became much too expensive and Surono and Ratmi were forced to borrow from a moneylender, whom they had to pay thirty per cent interest per month. Ratmi:

After we paid back that debt we said to ourselves that we would never borrow from a moneylender again. The loans from the simpan pinjam are much nicer because their interest is only two per cent per month. But you never know. Maybe one of us will have to go into hospital; we pray to God that it will not happen, but that could cost us more than we can afford. Normally we can sell our gold, and we have some money in the bank and our arisan and simpan pinjam, but it might just not be enough. In that case we might go to a moneylender again. The problem with the arisan and simpan pinjam is that you cannot always get money at exactly the moment you need it. Therefore we have some savings in the bank. A lot of people here in Bujung always go to a moneylender when there is a sudden necessity.

Afterwards they wait for the meeting of the UKK in order to borrow an amount that they can use to repay their expensive debt with the moneylender.

Surono and Ratmi's bank account has an important role in their financial strategies. Ratmi:

We have a bank account where we bring our extras. When the big sums from the arisan come in we usually bring them to the bank first, before we spend them on the expenditure we planned. When there are good days at Malioboro we usually take the money home and save it there. When it has gone up to a few hundred thousand rupiahs we take it to the bank.

\section{IRWANTO AND GUNEM}

Irwanto and Gunem are in their early fifties and living along one of the rivers in Bujung. They have four children, two daughters and two sons (aged twenty-three, sixteen, nineteen and ten respectively). During the period of my fieldwork the oldest daughter married and had a daughter. Her husband moved in with her parents until the couple found a place for themselves. 
The second daughter went to Jakarta after she had finished junior high school, to receive training as a nurse. The eldest son works in a nearby repair shop and the youngest son is still in primary school. Irwanto himself has a variety of jobs. His main job is digging wells, and he can earn a higher than average income during the dry season. When he is not busy doing this, he tries to look for jobs as a construction worker. The rest of his time is spent digging sand from the river. Irwanto also has a pedicab, but he more often uses it to go to work than as a source of income. Gunem works as a maid for a Chinese family in another part of the city. There she earns a regular monthly income, with additional bonuses for extra jobs such as shopping and massages. At home, she and her daughter occasionally spend time making strings of artificial flowers, which are sold to a trader to be used at weddings.

Like Surono and Ratmi, Irwanto and Gunem participate in a lot of financial self-help organizations, but they are not always happy with this. One day Irwanto complained to me:

Life is very difficult now. [...] The problem is that I do not have any work in prospect. [...] This month [January] is always very quiet. In the end I used some money left over from shopping by my wife. I need a lot of money to repay debts. In all the simpan pinjam that we follow we have debts, in the men's and the women's arisan in the RT, Dasa Wisma, Hansip Kecamatan, Hansip Kampung, and the simpan pinjam for the leaders of the RT. ${ }^{22}$ There is no way in which I can borrow from any of them right now. When I have repaid those debts, I will certainly borrow from all of them again. Then we also have to pay all the arisan that we follow, the five I mentioned, the arisan for the youngsters, the weekly arisan at the mosque, the monthly arisan with $\mathrm{Bu}$ Wasiran. For these arisan and simpan pinjam Rp. 100,000 per month is not enough. I really wonder whether I will be able to follow Bu Surat's arisan again when it restarts next month. All these things start to play in my head. If you do not keep control of it you are gone. Apart from this I also have various loans with neighbours, but not that much, and I do not borrow large amounts from the moneylenders. But I also have to think of the weekly savings for the youngest child at the pengajian [Islamic lessons] in the mosque and at school we also save money for our children. And I've not finished yet. This week two people in this neighbourhood died. I had to pay contributions of $\mathrm{I}, 000$ per person. My wife pays the same amounts through the women's arisan. Then we have to pay for the construction programme of our RT, the yearly picnic, etc. Then we also have to pay school fees for two children, Rp. 13,000 per child per month. I have not even mentioned our daily food. [...] Whoa, life is hard these days. I completely depend on people for whom I have worked, who feel sorry for me and give me some extra money. The problem is also that at the moment I cannot take jobs for digging wells because my partner's back hurts and he cannot bear hard work now. Alone I cannot dig any wells.

22. Hansip stands for Pertahanan Sipil, the local voluntary civil guard platoon. In his position as head of the security section in his RT, Irwanto attends the meeting for leaders of the RT. 
It is clear that Irwanto is exaggerating at least a little and mentions expenditures twice in order to "sweeten" his story, but the quotation exemplifies how many worries and headaches Irwanto and Gunem have in balancing their income and expenditure. The financial self-help organizations appear only to contribute to the problems. Irwanto and Gunem spend less on self-help organizations than Surono and Ratmi, but they also have a much smaller and more insecure income. One main difference is that Irwanto and Gunem are not engaged in business. Their main priority lies with their house, which they recently purchased. The house is in a bad condition compared to most other houses in the alley. Irwanto continues:

When I borrow from a simpan pinjam I have to use all the money for the expenditures I mentioned. I have already received both kitties from the big arisan I'm in. My plans for improving my house will have to wait. I would like to participate in UKK [...], but I just cannot afford it. Even if I were able to pay the initial contribution of Rp. 100,000 the loan repayments would be too heavy for me. Kalau dapat uang senang-senang, kalau harus membayar nyut-nyut [When we receive money we are happy, but when we have to pay our hearts are thumping]. The problem is also that there are more and more activities that require money. Today we have the arisan for the youngsters again. I've never had so many debts as now. I cannot afford to fall ill at the moment. There is no money.

Sometimes Irwanto and Gunem can use lump sums from financial self-help organizations directly to pay school fees, to buy cement or, like when Irwanto received the kitty from the men's arisan in the RT, to buy raw materials for his wife to make flowers. Sometimes they are able to save money in the house or buy gold, as savings in kind. However, most of the time they are forced to spend that money on repaying debts with moneylenders, neighbours or other simpan pinjam. If a lump sum arrives, Irwanto and Gunem may not always agree on the purpose for which it will be used. After a meeting of Hansip for example, Irwanto told me that he wanted to use the kitty to buy cement for his house. But Gunem overheard us and she immediately claimed the money: "It is for paying school fees, and Rp. 20,000 has to be used to repay the money we borrowed from Sabarno" (their neighbour, from whom they borrowed money to repay a debt to a friend).

\section{DISCUSSION}

\section{Mix of motivations}

Both the Surono family and the Irwanto family participate in a large number of financial self-help organizations, considerably more than the average household in Bujung. In that sense, these two households should be seen as extreme examples. For Surono and Irwanto, as for most people in Bujung, considerations of social obligation play a role in their motivation to participate in financial self-help organizations. Javanese urban wards are close-knit 
communities where good contacts between neighbours are highly valued. Participation in financial self-help organizations is one of the ways in which this is expressed, and nonparticipation in neighbourhood organization is perceived as tantamount to saying that one is not interested in one's neighbours. In that sense, participation is in many cases "compulsory". It is also no coincidence that Surono mentions social motivations as the first and foremost reason to participate in self-help organizations. It is the exemplary socially desirable answer. However, we can also see from the case studies that the Surono and Irwanto families, like many other households in Bujung, also make use of the financial resources derived from financial self-help organizations. The main attraction of these institutions is that they appeal to a balanced mix of motivations that can be both financial and social in nature.

\section{Female paradox}

We also saw that when Irwanto had received the kitty from the arisan Hansip, the money was "confiscated" by his wife Gunem, who eventually decided what the money was going to be used for. In Bujung, financial self-help organizations are a major object of discussion and negotiation within Bujung households. Scholars too often implicitly assume that the person who is a participant of a financial self-help organization and who attends the meetings is also the one who pays the contributions and spends the money. The reality can be different.

With regard to this, there seems to be a paradoxical contradiction when it comes to female participation in self-help organizations. What happens in financial self-help organizations is basically that small sums are converted into lump sums. In the cultural context of Bujung households this means that through arisan and simpan pinjam shopping money (or pocket money) is turned into stocked savings. Even though women generally have more to say about lump sums derived from self-help organizations in which they themselves participate, in the process of participation women lose considerable decision-making power over their money. Why then are women more actively engaged in financial self-help organizations than men?

One explanation sometimes suggested is that participation in financial self-help organizations is a secret affair and offers a way for wives to conceal money from their husbands. ${ }^{23}$ In the context of Bujung this does not seem to make much sense since the meetings are social events, and saving in self-help organizations can never be as secret as a secret jar at the back of a cupboard. It seems more logical to suppose that women participate because they have to cover financial disparities and cope with larger expenditures in the household, and that they take the involvement of their husbands for granted. By participating in smaller self-help organizations, they can build

23. Ardener, "Women Making Money Go Round", p. I5. 
up lump sums that are large enough to be useful and small enough not to arouse the suspicions of their husbands. To some degree, women can use their participation in financial self-help organizations in negotiations with their husbands and bargain for more shopping money. Nonetheless, without a doubt, women with more cooperative husbands, who have an eye for the interests of the household, might benefit more from the potential offered by a financial self-help organization.

\section{Right balance}

Turning to the techniques used to cope with financial disparities, participation in financial self-help organizations shows the advantage of illiquidity as well. Not only is the money contributed to a financial self-help organization inaccessible most of the time, there is also an obligation to save and contribute on a regular basis. This is an extra advantage, one that piggy banks and savings in kind lack. With regard to this phenomenon, De Swaan speaks of self-constraint through social constraint leading a person to be an exemplary saver. ${ }^{24}$ Social pressure, together with potential feelings of embarrassment if one cannot pay, makes participants eager to fulfil their financial obligations. Informants frequently mentioned this mechanism as the primary reason to participate in self-help organizations: "Without arisan I cannot save. If I save in the house, I spend my money too easily." Without the self-constraint component of arisan and simpan pinjam, Surono and Ratmi would have found it much more difficult to save for the investments they made to expand their business. Depending on the income of a parking guard alone would never have allowed them their present standard of living, nor would they have been able to consider higher education for their children, as they do now. But also, it has made their household less vulnerable to financial adversities; they have built up assets and creditworthiness that can be mobilized in times of need.

Obviously, the preference for illiquidity is not absolute because money still has to be accessible for the "right" purposes, such as school fees, hospital costs, etc. If spending constraints are too strong, new insecurities emerge, as we have seen from the example of the Irwanto family, and they can often only be accommodated at high cost. Surono and Ratmi were forced to borrow from an expensive moneylender, even though they had stocked large sums of money in financial self-help organizations. Also, with regard to the future, Ratmi doubts whether funds from arisan and simpan pinjam would be readily available if she had to be admitted to hospital. Dramatic examples

24. A. de Swaan, "Onderlinge Fondsen: Toen en hier nu en daar", in M. van der Linden and J. Sluijs (eds), Onderlinge Hulpfondsen (Amsterdam, 1996), pp. 9-22, 12. The argument is further developed in A. Bijnaar, "Wat je zaait zal je oogsten!: Dwang en Zelfdwang in Creools-Surinaamse Onderlinges", Amsterdams Sociologisch Tijdschrift, 25 (1998), pp. 329-370. 
of this problem are the several people in Bujung who, because of sudden high expenditures, were forced to sell the kitty of their arisan before they received it. In that case, they receive an amount equivalent to only around half its value, while they have to keep paying their regular contributions. In spite of their desire to save, people also want to avoid such situations and therefore look for the best balance between liquidity and illiquidity.

Participants can also opt for a different approach, using financial self-help organizations as a means to repay debts with debts. This entails using the lump sums they are about to receive as collateral for other loans. ${ }^{25}$ We have seen the example of Gunem, who borrowed from her neighbour, promising that the debt would be repaid as soon money is received from an arisan or simpan pinjam. Gali lobang tutup lobang is the only way Irwanto and Gunem can get through the lean wet season, and they resort to it every year. The more financial self-help organizations they join, the more flexible they are. A very large part of the lump sums derived from financial self-help organizations in Bujung is directly used to repay debts. ${ }^{26}$ Such repayments can sometimes be witnessed at the meeting itself or immediately afterwards. Not only do people use lump sums from financial self-help organizations to repay debts, the reverse also occurs. Surono and Ratmi borrow money to pay instalments and contributions to self-help organizations, mostly from the other organizations in which they participate. Other sources of credit are frequently used for this purpose as well. In the hours before the meeting of a financial self-help organization one can often see people roaming the alleys, approaching neighbours, looking for cash to pay their contributions.

People do not always voluntarily engage in gali lobang tutup lobang. If they have no ready cash, they can choose only between default and taking a loan to repay the debt. Given that they face huge social pressure to pay their contributions, the choice is easy for most people. But if debts begin to exceed their irregular income peaks (rezeki), the debt cycle will get out of hand, with devastating results. The way to avoid this problem is, obviously, to maintain a safe margin between financial obligations and the average income surplus. Many people in Bujung are very careful in trying to do this and mention this as a reason not to participate in too expensive financial self-help organizations. They often point to people like Marzuki who have been less careful and have to juggle with their money in order to make their regular payments. However, this careful calculating attitude is in constant conflict with the illiquidity pref-

25. In discussing this issue, informants did not distinguish particularly between the use of arisan and simpan pinjam, even though the latter provides loans and the former does not.

26. It is very difficult to establish which part of the lump sums from financial self-help organizations is used for repaying debts. The practice is generally regarded as irresponsible behaviour, which leads to people being very secretive about it. Of the 109 respondents to our questionnaire who said they had ever borrowed money from a simpan pinjam, only 2.8 per cent said they had used it last time to repay debts. Based on my daily observations, interviews, and informal conversations I can safely say that this is a considerable underestimate. 
erence and the strategy of seeking self-constraint. More money than necessary can leak away, either to relatives and friends or to consumption. Again, it is important to find the right balance.

\section{CONCLUSION}

Much of the income of people in Bujung is insecure, and can vary from day to day and from month to month. Similarly, the costs that they have to incur are not evenly spread over the year. Payment of school fees, rent, hospital costs, etc. leads to difficult moments, and people find it problematic making ends meet.

Financial self-help organizations can play a role in cushioning financial adversities and deficiencies in five different ways, two of them direct and three of them indirect. Directly would be through disbursements from funeral funds and sickness funds, or by using a loan or kitty to bridge a financial disparity. The first option provides only limited financial relief, while the second seldom occurs. Participants are generally unable to influence the moment at which they receive the kitty and, mainly because participants of simpan pinjam tend to borrow continuously, loans are not readily available. Therefore, arisan and simpan pinjam are normally more useful for coping with financial disparities in an indirect way. Participants can use them as collateral for other loans, generally to repay debts with debts. Participants can use lump sums to invest in assets or put the money in the bank, thereby creating resources that can be mobilized in times of need. And finally, participation in financial self-help organizations can be useful for strengthening and expanding social networks. These last three practices are particularly relevant in the Bujung context.

In spite of the obvious usefulness of financial self-help organizations for household survival strategies, there is no reason for hallelujahs (or alhamdulillahs). In the process, new problems may emerge and payments can be a real burden for participants. The illiquidity of money in financial self-help organizations leads at least some households to enter a potentially expanding debt cycle. Obligations towards those organizations can force participants to accept expensive solutions, for instance in the form of a loan from a moneylender or the sale of a kitty yet to be received. Partly, this is the result of having to walk the line between illiquidity and flexibility. However, it is also important to be aware that participation in financial self-help organizations cannot be purely understood as a goal-oriented and strategic activity. In Bujung, participation is largely a habitual activity, motivated by a desire to be a good member of the "community" and to conform to the expectations of others. The challenge for participants is to use the financial resources offered by financial self-help organizations as effectively as possible. While having to cope with insecurities, they have to cope with arisan and simpan pinjam as well. 